University teachers'

digital stories of

sustainable develop-

ment: A method of

learning to teach

Satu Hakanurmi

KM, kehittämispäällikkö

Turun yliopisto

satu.hakanurmi@utu.fi

\section{Tuire Palonen}

$\mathrm{KT}$, yliopistotutkija

Turun yliopisto

tuipalo@utu.fi

\author{
Mari Murtonen \\ $\mathrm{KT}$, professori \\ Turun yliopisto \\ mari.murtonen@utu.fi
}




\section{Abstract}

In order to help teachers teach sustainability more effectively, we need more knowledge about both their understanding of suitable pedagogical methods and their own positioning in regard to sustainable development. This qualitative research focuses on how teachers see themselves as educators of sustainability and how they experience creative methods such as digital storytelling in supporting their learning. Interviews were carried out with nine university teachers during a staff training course on sustainable development and how it is best taught and learnt. Findings indicate that teachers' positioning in regard to the teach- ing of sustainable development varied according to their discipline and their understanding of its four dimensions, namely ecological, social, economic and cultural. Digital storytelling thus proved to be a promising method for supporting holistic learning and teachers' self-positioning in regard to education concerning this complex domain. However, some restrictions exist in relation to resource-taking and teachers' need for additional support.

Keywords: sustainable development, digital storytelling, education for sustainable education, positioning, identity, university teaching, pedagogical skills

\section{Models for teaching sustainable development}

Higher education teachers play a central role in teaching sustainable development. The situation is problematic if teachers feel that sustainability is not part of their own discipline, that they lack the knowledge, skills and experience to teach it, or that they have to learn how to do so by themselves (Jones et al., 2010; Stephanos et al., 2020, p. 275). Sustainable development is most commonly related to and understood through the natural sciences, particularly biology and geography (Cantell et al., 2019). However, to promote climate-responsive action, it is necessary to understand social sciences, health sciences and politics, together with ethical and humanistic perspectives, so that students are better-informed, environmentally-sound future decision makers (Andrew, 2014; Cantell et al., 2019; Hens \& Stoyanov, 2014; Laine, 2016). Since the Brundtland Commission report in 1987 , the concept of sustainable development has devel- 
oped to encompass ecological, economic, social and cultural dimensions (Soini \& Birkeland, 2014). The social and cultural dimensions, in particular, require the promotion of values and worldview as the basis of sustainability (Chiu, 2004; Laine, 2016).

Students graduating from universities that prioritise holistic education about environmental issues are better prepared to meet the sustainability challenges of the future as well as in the job market (Andrew, 2014). For education in sustainability to be effective, teachers must be aware of all four dimensions and have sustainability-compatible values and worldviews, as well as suitable methods to teach sustainable development holistically.

Several models for education for sustainable development exist. Palmer's classical tree model (Palmer, 1998) includes components of education about, in and for the environment, while the bicycle model developed by Cantell and colleagues (2019) encompasses knowledge, thinking skills, values and worldview, identity, motivation and participation, and future orientation, together with operational barriers, hope and emotions.

All education for sustainable development models stresses the active role of learners and a future-oriented perspective. Teaching methodologies such as project-oriented learning and cross-disciplinary workshops have proven excellent for developing competencies in sustainability (Cebrián et al., 2020). The key competencies to promote sustainable development are critical thinking, coping with uncertainty, adaptability, creativity, dialogue, respect, self-confidence, emotional intelligence, responsibility and systemic thinking (Cebrián et al., 2020).
A suitable pedagogy for sustainable development can be grounded in the models outlined above. However, the holistic character of sustainable development challenges teachers' professional identity. To understand how teachers learn sustainable development, we need narrative research.

\section{Positioning}

Positioning is a widely used concept in examining the negotiation of identities (Bamperg \& Georgakopoulou, 2008). It refers to the constitutive and paramount storylines in the organizational structure of discourses used by people to make sense of their experience and future agency (Depperman, 2015). People are also positioned by others' acts ('other-positioning'), through questioning, resisting or affiliating. Positioning happens during an interaction as a discursive process, and it defines the rights and duties of actors (Harré \& Van Langenhove, 1991; Harré et al., 2009). "In interactive situations, positions and theories collide and interact like waves, creating diffractive patterns and new insights about phenomena, and there is a relationality of concept and object" (Barad, 2014; de Freitas, 2017, p. 742). In sustainability education, positioning in socio-categorical relationships, such as discipline/teacher/student, is a constant discourse between generations, sciences and society.

Understanding positioning processes, including the actors' own thinking and interaction with others, requires experiments and methods that enable an atmosphere of 'being in touch' (de Freitas, 2017). The cultural dimension of sustainable development, in particular, requires a mindset which is dynamically open to new ideas and agencies, which is chal- 
Life unfolds as a narrative, with multiple interlinking

\section{storylines.}

lenging for teacher identity. For example, it is affected whether teachers conduct research on sustainable development or need to tackle holistic and cultural aspects of sustainability in their own work. "In narrative research, the current interactional approach stresses that participants actively project and self-negotiate their positions" (Bamberg \& Georgakopoulou, 2008; Depperman, 2015, p. 370).

\section{Narrative learning and digital stories}

Life unfolds as a narrative, with multiple interlinking storylines (Harré et al., 2009). Narratives also serve to enhance future agency by offering renewed identity, values and agency (Hakanurmi et al., 2021). One of the most modern forms of narratives is digital stories: autobiographical mini-documentaries lasting between one and three minutes during which the storyteller combines his or her personal experiences and worldview with scientific theories, sociocultural values and practices (Hakanurmi, 2017).

Digital storytelling is regarded as both a method and a movement to give people a voice through devices such as tablets, computers and mobile phones (Kaare, 2012). When storytellers explain their identities to each other, they exercise transformative power, and the simple format of digital storytelling leads storytellers to construct personal narratives with the shared and collective values of a community (Kaare, 2012; Lambert, 2002). The narrating selves touch each other's identities and promote a collective identity (Kaare, 2012).

Pedagogically, the power of digital storytelling is connected to its ability to support transformative learning and its impacts on professional growth and development (Anderson, 2017; Mezirow, 1991). Storytellers become something else and make meaning of their experiences. The process consists of a disorienting dilemma, self-examination, recognition, planning a course of action and reintegrating the new perspective into one's life (Merriam \& Bierema, 2014; Mezirow, 1991). Digital storytelling encourages to combine the professional and personal, which Clandinin and Connelly (1987) refer to as 'personal practice knowledge'.

To conclude, narratives are mediums to express and negotiate individual and collective identities. Positioning theory, a central theory concerning narrative identity, highlights the interaction between the storytelling self and the story world as a discursive process (De Fina, 2015). According to Bamberg (1997), the narrator can position herself at three levels: a story world, with protagonist and antagonist and evaluations of their actions and responsibilities; in regard to the audience, in order to say something about her present self; and according to how she wants to be seen more generally, by answering to the question 'who am I'.

Jamissen and Moulton (2017) investigated digital storytelling as a tool to strengthen collaboration in an interprofessional faculty group. They found that digital storytelling is a potential boundary object for promoting reflection and mediating interprofessional collaboration and the meaningful integration of disciplines, 
as well as a potential means to mediate improved understanding and communication, as there were signs of increased trust and shared tacit knowledge among the group (Jamissen \& Moulton, 2017). Similarly, Edwards $(2011,2017)$ and Edwards et al. (2010) posits that relational agency requires an understanding of other disciplines and their aims, practices and values.

This study presumes that digital storytelling supports education for sustainable development by inspiring discussion and reflection on one's own values, experiences and positioning in a multidisciplinary context (Hakanurmi et al., 2021; Jamissen \& Moulton, 2017).

\section{Research questions}

Taking into consideration the literature and the need to know more about how teachers think and learn about education for sustainable development, we defined the following research questions:

Research question 1. How do teachers from different disciplines position themselves regarding education for sustainable development?

Research question 2. How is digital storytelling experienced as a learning method for sustainable development?

\section{Methods}

\section{Participants and Context}

$1 \begin{aligned} & \text { three-credit-point (81-hour) staff } \\ & \text { training course, Video Stories of } \\ & \text { Sustainable Development, was }\end{aligned}$ held at the University of Turku in spring 2021. Of the ten participants, one did not consent to be interviewed. All par- ticipants were women, and all except one were simultaneously studying the 60-credit-point University Pedagogical Studies programme. Three were university teachers. The rest were researchers or had some other position at the university, including teaching duties. Participant ages varied between 30 and 59, while teaching experience ranged from 1.5 years to 20 years.

Participants' background in sustainable development varied based on their earlier or current work. Three participants worked or had worked in industries which are regulated by environmental legislation. Participants in a researcher position $(n=3)$ reflected sustainable development when preparing funding applications for the Finnish Academy or supervising their students' master's theses.

Participation was voluntary, and the principal motives for attendance were to learn video production and develop ideas for education for sustainable development. A majority $(n=8)$ of the participants assessed their own skills as video makers at zero. Participants represented different faculties and thus provided a multi-disciplinary forum for discussions of sustainable development.

The first part of the course oriented participants toward the goals and pedagogical models of sustainable development. During the second part, participants collaborated to produce their own digital story, facilitated by the teacher support unit. Using the preliminary assignment and self-study materials, the participants were asked to tell a personal digital story about sustainable development as part of their work. Each participant made a more strict circumscription independently. Digital stories documented teachers' own positioning in the promotion of a sustainable future. 


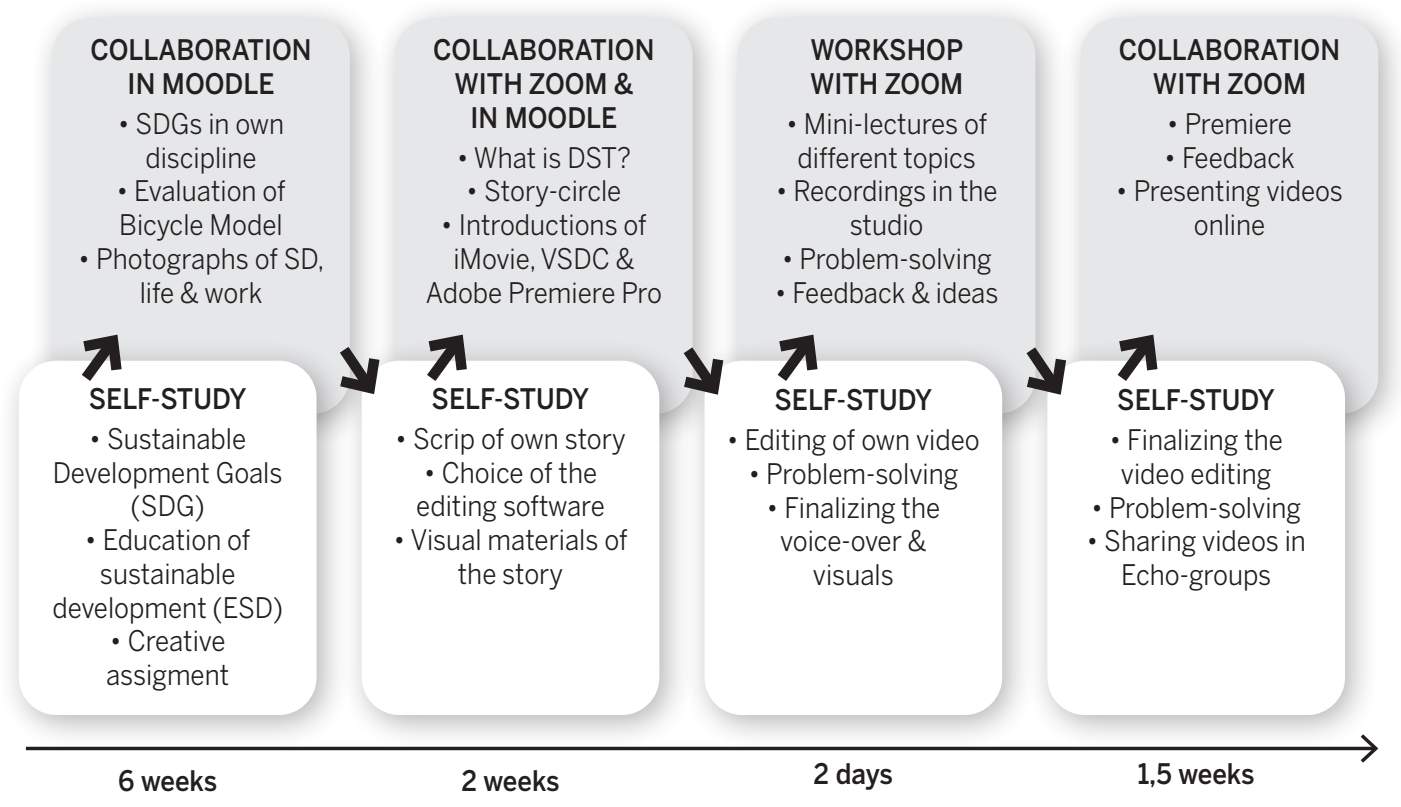

Figure 1. Video Stories of Sustainable Development: an online course combining selfstudy, group discussions, mini-lectures and synchronous story-circle, workshop and premiere on Zoom.

\section{Data and analysis}

Data was gathered during nine interviews conducted before (approximately $50 \mathrm{~min}$ utes) and at the end of ( 40 minutes) the course, as well as the digital stories produced by the participants. The first author of the article developed the course design, taught part of the course and conducted all interviews. The first interview addressed sustainable development in a university context; the second focused on participants' reflection on the learning process in general and experiences in learning with digital storytelling. The researchers watched the produced digital stories together.

All interviews were transcribed verbatim and read by all writers. The interviews were analysed according to positioning theory (Bamberg, 1997), using the methods of qualitative content analysis and fea- tures of narrative analysis, and the analysis result was agreed by all writers. Bamberg's (1997) positioning theory provided a sound theoretical background to analyse interviews and digital stories both separately and together as a continuation of storylines that describe teachers' identities and positioning in the area of interest in three parts: 1) How they positioned themselves as teachers of sustainable development before the course; 2) How they positioned themselves in regard to the audience in their digital stories; and 3) How they positioned themselves as teachers of sustainable development after the course. Themes formed according to Bamberg's (1997) theory were tested by all writers; discrepancies were discussed in the meetings of the research group. 


\section{Results}

$\mathrm{E}$ ducation for sustainable development most obviously posed a challenge for teacher identity, and it appeared the participants felt the need to position themselves within this field. Depending on their discipline, work, life stories and current knowledge of sustainable development, teachers adopted either natural professional positions or more distant generalist positions. All participants found that the process of digital storytelling promoted interactional positioning. The combination of new knowledge, reflection on own identity and listening to others' stories widened participants' understanding of sustainable development and teaching methods and simultaneously offered a forum for them to position themselves as teachers. Participants from various disciplines recognized ways of promoting sustainability in their own field, even when their own discipline did not offer a direct related research context.

\section{Positioning according to different disciplines}

A natural positioning happened when a teacher's own research area had a clear connection to sustainable development. The possibilities of promoting sustainable development directly in one's own research and teaching provided a strong identity for education in sustainable development. The teacher identity around sustainability issues began to blur when their own research interests lay elsewhere, in which case they used research and methods developed by others, such as the eco-critique in literature studies. In disciplines where the research area has few connections to different dimensions of sustainable development, other sustainable development practices were found.
In medicine, for example, open science and open research data increase sustainability and are already practised, at least in research projects funded by the Academy of Finland. Other positionings meant, for example, gender equality in fields dominated by men or a systematic way to evaluate subcontractors' sustainable development profiles. "I now borrow my boss' slogan: s/he said that once-used research data can be reused. This also applies to archive materials. Yes. I think this is the biggest narrative."(I6a)

The researchers in the economic field provided ideas for and examples of teaching the economic dimension of sustainability, as expected. The accreditation of the School of Economics had renewed its aims; for each teacher, however, methods of teaching sustainable development goals (SDGs) remain unclear, even though examples exist of how to integrate sustainability into education. The innovation plans produced in groups, as well as the lifecycle analysis of products and services and overall impacts and outcomes of business in different countries, were successful pilots but lacked the background theory of education for sustainable development.

“.... in education for sustainable development, even though I had done it myself already, in my courses, I really liked those [pedagogical] models like the bicycle model. Then I started to think, what is most important? So, just like the role of values and future orientation, I thought, I must think about my teaching from that perspective - how I could somehow add to the discussion of values there." (I7b)

The uncomfortable emotions expressed during the first interview changed during the course into different teacher identi- 
ties which were suitable for teaching sustainable development in their own field. Some teachers were already more sustainability-aware than others when the course began, but interactional methods such as digital storytelling offered a variety of goals and ways to teach sustainable development. Teaching sustainable development requires teachers to be open to knowledge and collaboration with other disciplines. When problems are wicked, solutions to them do not lie in a single discipline.

The interactional positioning in the middle of pluralistic storylines transformed teacher identities and enhanced teacher agency as researchers or generalists in education for sustainable development. The latter implies the promotion of general skills in academic education, such as critical thinking, analysing conflicts of interests and supporting all students equally.

\section{Positioning between the four dimensions of sustainable development}

The ecological dimension seemed to be a self-evident part of climate-responsive action and dominated the participants' concept of sustainable development. When participants familiarised themselves with all the SDGs of the United Nations, their understanding widened to cover all four dimensions (ecological, economic, social and cultural). "At least I have learnt a huge number of new things about sustainable development in general and what a diverse concept it is... I hadn't thought before about how comprehensive it is. " (I2b)

The ecological dimension was also a starting point in participants' own storytelling, although their stories also covered other dimensions. Participants involved in social science research activities $(\mathrm{n}=3)$ found it easier to understand the extension into the social dimension, which appeared to require reflection for those coming from other disciplines $(n=6)$.

"This opened up for me a much larger view on sustainable development, just by providing these kind of equality discourses and so on, which is extremely important, but I only now recognize them as somehow belonging under this umbrella. This was interesting and useful, of course." (I8b)

The Anthropocene worldview in general challenges also the ecological dimension that is changing (Fedosejeva et al., 2018). Only four participants mentioned the cultural dimension at interview, while five still lacked knowledge in this area when the training ended. The cultural dimension requires serious reflection on how we understand life circumstances now as constant economic growth and life as consumers. If the teacher or students deny the values and normative character of the actions needed for climate change and other SDGs, the situation becomes more challenging during studies and, later, at work.

For participants from other disciplines, except business education, the sustainable economy remained unclear, with some exceptions. Collaboration with researchers in the field of social sciences, political research and economics, for example, might open up new perspectives.

"Of course, for example, with business school, where I expect these things are under reformulation, it would be interesting to offer this perspective of business history in the sense that this is not actually a fresh issue and that these critical voices are also worth recognizing when we try to 
support the agency of people and the possibilities to choose differently." (I4a)

\section{Positioning through personal life history in digital stories}

Storytellers positioned themselves on the stage and wanted others to see them in line with their disciplinary positions. While sustainable development was connected to their own research and interests at work, storytellers also included elements from their personal life history, such as anecdotes from their childhood and references to their grandparents and own children. Storytellers with weaker connections to sustainable development in their own disciplines placed personal life histories at the centre of their narratives, where they represented a variety of sustainable development dimensions. Storytellers typically referred to their relations with nature and consumption and reflected on different generations, periods of history and societies. Reflection on both personal and professional aspects of sustainable development enabled it to be viewed holistically, with attention paid to values, worldview, identity and future orientation, as well as operational barriers, hope and emotions, as expected by the bicycle model.

\section{Digital storytelling and learning}

Digital storytelling proved a suitable method to learn the content of sustainable development and how to teach it. In interactional discourses, personal, discipline-specific and holistic narratives overlap in multidisciplinary contexts. However, many challenges remained to constructing personal digital stories. The assignment - tell a subjective story - faced resistance from research-oriented partic- ipants $(n=2)$, who wanted to include a strong professional perspective in order to use the story as learning material for their own students.

\section{"I was shy about making a subjective} story, if I planned to use it in my own teaching, as it was suggested that we might use these in teaching... I thought that my own personal input would take away something very important, and it was important for me to find the professional perspective." (I8b)

This is a revealing quote, because it describes how the role of videos is often understood in education: to enable the teacher to share knowledge. When telling their own stories, the teachers started to consider videos' other functions and noticed that their students might do digital stories too. Teachers thought they lacked the media skills to supervise their students; hence, they need support when starting to use innovative teaching and learning methods such as digital storytelling.

The introduction of the course provided common ground for discussion and an atmosphere of safety and trust so personal stories could be told. Teachers experienced the chaos was easier to stand when other participants had the same difficulties with their storylines.

\section{"About the story-circle - that worked} nicely. It was encouraging, with a good atmosphere. Nobody was sitting there like, I'm only here because I have to be, because nobody had to. But the case was that it was a very good team spirit that is not necessarily self-evident that it is, and in the premiere, everybody got beautiful feedback and respect, meaning the stories were seen as valuable." (I4b) 
The participants' notions of trust, respect and learning from others' digital stories may be seen as signs of boundary objects in finding productive ways to build a working combination of diversity and unity instead of creating consensus (Akkerman \& Bakker, 2011; Jamissen \& Moulton, 2017; Leigh Star, 2010).

The digital storytelling workshop was a turning point for participants' teacher identity, in education for sustainable development. The participants reported a better understanding of other disciplines after the course, supporting earlier research indicating that digital storytelling has potential as a boundary object to mediate interprofessional collaboration and integrate disciplines (Jamissen \& Moulton, 2017). Collaboration during digital storytelling clearly offered teachers a forum for identity work, and storytelling supported relational agency regarding understanding different disciplines and, in general, gaining insight into the purposes and practices of others (Edwards et al., 2010).

All participants shared that they had learnt a great deal from the stories and their colleagues' mindsets.

"I was surprised how much I could get out of them when I was watching them... I had a general overview of sustainable development, but I learnt new things through the materials but also from the [video] presentations of other participants that I hadn't thought of before..." (I5b)

"They opened my eyes, those videos made by others." (I6b)

"Even though the videos were different, so I clearly watched them closely and paid attention to many things." (I7b)
"It was very inspiring to see how others had solved similar kinds of things to what I was reflecting on." (I8b)

The production and use of videos inspired the teachers and made them think about their own teaching. One teacher suggested organising workshops for students from different disciplines interested in producing a video instead of another output, such as an academic essay, and letting them learn in an interdisciplinary context. This idea supports the argument that a digital storytelling workshop and listening to others' stories promote holistic understanding of sustainable development and enable connections to be built between disciplines. This valuable notion addresses how we can prepare students for interdisciplinary collaboration. It is of the utmost importance to train students to have relational agency and act as 'interactants' rather than as singular actors (Burkitt, 2016; Edwards, 2017).

\section{Discussion}

The findings of this study have important implications for future practice. To provide knowledge and information about sustainable development is obviously not enough for either teachers or students. The aims for education for sustainable development described in the bicycle model call for a method that allows a holistic reflection of values, worldview and identity (Cantell et al., 2019). Combining knowledge and reflection of teachers' own values and positionings produced multiple storylines by means of digital storytelling that enabled a discursive practice and interactional contingencies. Even loose and distant connections between the participants' own work and sustainable development transformed into positionings which they can trans- 
late into their work toward sustainable futures. Similar processes are important in academic studies where, in parallel with specific learning outcomes, the aim is to educate professionals to fully realize their role in building a better world according to all the SDGs.

This study revealed that the teachers had quite limited views of sustainable development before the course; however, after learning about the four dimensions of sustainable development both personally and collaboratively in narratives, they could conceptualize sustainable development more broadly in relation to their own discipline and their work as teachers (Bamberg, 1997; Clandinin \& Connelly, 1987; De Fina, 2015; Depperman, 2015). Their personal relationship to sustainable development and listening to others' digital stories taught them various ways to think about sustainable development.

Apparently, teachers regarded digital storytelling as a decent practice in higher education learning, with some restrictions. It proved to be successful for teaching a complex domain such as sustainable development in a multidisciplinary context (Jamissen \& Moulton, 2017; Kaare, 2012; Lambert, 2002). A course in digital storytelling was a concrete way to teach teachers a new method. When implementing digital storytelling in their own teaching, the teachers need additional support in pedagogical, narrative and technical matters. Digital storytelling is a resource-taking activity, which may restrict its use in academic teaching. However, creative and innovative teaching methods are welcome when learning outcomes deal with values, identity or agency, as in the tree model or bicycle model (Cantell et al., 2019; Palmer, 1998). Simply reflecting on experiences might not be enough; a wider knowledge-base is necessary at all phases of storytelling, together with collaborative reflection of experiences and meaning-making. Transformative learning means deep, personal, collaborative and holistic reflection, including all dimensions of sustainable development (Anderson, 2017; Mezirow, 1991).

The digital storytelling process during the course was a matter of gaining sufficient insight into the purposes and practices of other disciplines to enable collaboration also in the future (Edwards et al., 2010; Edwards, 2011; Edwards, 2017). However, the participants appeared to have no plans to continue collaboration afterwards or build relational agency in practice. The lack of willingness to collaborate and thus practise relational agency needs further research.

A common challenge for university teachers is to consider a sustainable development perspective in their own research and teaching, as well in other university practices. Positioning one's own teacher identity offers a sound background for teaching sustainable development. As a whole, the university can best teach sustainable development when teachers are equipped with the identities, knowledge and methods necessary to educate new generations.

\section{References}

Akkerman, S. F., \& Bakker, A. (2011). Boundary crossing and boundary objects. Review of Educational Research, 81(2), 132-169. https://doi. org/10.3102/0034654311404435

Anderson, K. M. (2017). Let's get personal: Digital stories for transformational learning in social work students. In G. Jamissen, P. Hardy, Y. Nordkvelle, \& H. Pleasants (Eds.), Digital storytelling in higher education - International perspectives (pp. 7389). Palgrave Macmillan. 
Andrew, M. W. (2014). Developing faculty-staff collaborations to foster a culture of environmental justice. Georgia Journal of College Student Affairs, 30(2), 68-97. https://doi.org/10.20429/ gcpa.2014.300206

Bamberg, M. (1997). Positioning between structure and performance. Journal of Narrative and Life History, 7(1-4), 335-342.

Bamberg, M., \& Georgakopoulou, A. (2008). Small stories as a new perspective in narrative and identity analysis. Text \& Talk; Text \& Talk - an Interdisciplinary Journal of Language, Discourse Communication Studies, 28(3), 377-396. https://doi. org/10.1515/TEXT.2008.018

Barad, K. (2014). Diffracting diffraction: Cutting together-apart. Parallax, 20(3), 168-187. https:// doi.org/10.1080/13534645.2014.927623

Burkitt, I. (2016). Relational agency: Relational sociology, agency and interaction. European Journal of Social Theory, 19(3), 322-339. https://doi. org/10.1177\%2F1368431015591426

Cantell, H., Tolppanen, S., Aarnio-Linnanvuori, E., \& Lehtonen, A. (2019). Bicycle model on climate change education: Presenting and evaluating a model. Environmental Education Research, 25(5), 717-731. https://doi.org/10.1080/13504622.2019 .1570487

Cebrián, G., Junyent, M., \& Mulà, I. (2020). Competencies in education for sustainable development: Emerging teaching and research developments. Sustainability, 12(2), 579. https://doi. org/10.3390/su12020579

Chiu, R. L. H. (2004). Socio-cultural sustainability of housing: A conceptual exploration. Housing, Theory, and Society, 21(2), 65-76. https://doi. org/10.1080/14036090410014999

Clandinin, D. J., \& Connelly, F. M. (1987). Teachers' personal knowledge: What counts as 'personal' in studies of the personal. Journal of Curriculum Studies, 19(6), 487-500. https://doi. org/10.1080/0022027870190602

De Fina, A. (2015). Narrative and identities. In A. De Fina, \& A. Georgakopoulou (Eds.), The handbook of narrative analysis. blackwell handbooks in linguistics (pp. 351-368). Chichester: Wiley. Retrieved from https://utu.finna.fi/Record/volter.1757043

de Freitas, E. (2017). Karen barad's quantum ontology and posthuman ethics: Rethinking the concept of relationality. Qualitative Inquiry, 23(9), 741-748. https://doi. org/10.1177\%2F1077800417725359

Depperman, A. (2015). Positioning. In A. De Fina, \& A. Georgakopoulou (Eds.), The handbook of narrative analysis (pp. 370-387). Wiley.
Edwards, A. (2011). Building common knowledge at the boundaries between professional practices: Relational agency and relational expertise in systems of distributed expertise. International Journal of Educational Research 50(1), 33-39. https://doi. org/10.1016/j.ijer.2011.04.007

Edwards, A. (2017). Revealing relational work. In A. Edwards (Eds.), Working relationally in and across practices: A cultural-historical approach to collaboration. Cambridge University Press.

Edwards, A., Lunt, I., \& Stamou, E. (2010). Inter-professional work and expertise: New roles at the boundaries of schools. British Educational Research Journal, 36(1), 27-45. https://doi. org/10.1080/01411920902834134

Fedosejeva, J., Boče, A., Romanova, M., Iliško, D., \& Ivanova, O. (2018). Education for sustainable development: The choice of pedagogical approaches and methods for the implementation of pedagogical tasks in the anthropocene age. Journal of Teacher Education for Sustainability, 20(1), 157-179. https://eric.ed.gov/?id=EJ1218216

Hakanurmi, S. (2017). Learning to work through narratives: Identity and meaning-making during digital storytelling. In G. Jamissen, P. Hardy, Y. Nordkvelle, \& H. Pleasants (Eds.), Digital storytelling in higher education. Digital education and learning. Palgrave Macmillan. https://doi.org/10.1007/978-3319-51058-3_11

Hakanurmi, S., Palonen, T., \& Murtonen, M. (2021). Digital stories representing agency enhancement at work. Adult Education Quarterly, 71(3), 251-271. https://doi. org/10.1177\%2F0741713621989990

Harré, R., Moghaddam, F. M., Cairnie, T. P., Rothbart, D., \& Sabat, S. R. (2009). Recent advances in positioning theory. Theory \& Psychology, 19(1), 5-31. https://doi.org/10.1177\% 2F0959354308101417

Harré, R., \& Van Langenhove, L. (1991). Varieties of positioning. Journal for the Theory of Social Behaviour, 21(4), 393-407. https://doi. org/10.1111/j.1468-5914.1991.tb00203.x

Hens, L., \& Stoyanov, S. (2014). Eucation for climate changes, environmental health, and environmental justice. Journal of Chemical Technology or Metallurgy, 49(2), 194-208.

Jamissen, G., \& Moulton, M. (2017). "Now I see": Digital storytelling for mediating interprofessional collaboration. In G. Jamissen, P. Hardy, Y. Nordkvelle \& H. Pleasants (Eds.), Digital storytelling in higher education: International perspectives (pp. 243-259). Palgrave Macmillan. 
Jones, P., Selby, D., \& Sterling, S. R. (2010). Sustainability education perspectives and practice across higher education. Earthscan.

Kaare, H.B. (2012). The self and the institution. The transformation of a narrative genre. Nordicom Review, 33(2), 17-26.

Laine, M. (2016). Culture in sustainability - defining cultural sustainability in education. Discourse and Communication for Sustainable Education, 7(2), 52-66.

Lambert, J. (2002). Digital storytelling: Capturing lives, creating community. Digital Diner Press.

Leigh Star, S. (2010). This is not a boundary object: Reflections on the origin of a concept. Science, Technology, \& Human Values, 35(5), 601-617. https://doi.org/10.1177\%2F0162243910377624

Merriam, S. B., \& Bierema, L. L. (2014). Adult learning: Linking theory and practice. 1. ed. Jossey-Bass.
Mezirow, J. (1991). Transformative dimensions of adult learning. Jossey-Bass.

Palmer, J. (1998). Environmental education in the 21st century: Theory, practice, progress and promise. Taylor \& Francis Group. Retrieved from http://ebookcentral.proquest.com/lib/kutu/detail.action?docID $=169959$

Soini, K., \& Birkeland, I. (2014). Exploring the scientific discourse on cultural sustainability. Geoforum, 51, 213-223. https://doi.org/10.1016/j.geoforum.2013.12.001

Anastasiadis, S., Perkiss, S., Dean, B.A., Bayerlein, L., Gonzalez-Perez, M.A., Wersun, A., Acosta, P., Jun, H. and Gibbons, B. (2021). Teaching sustainability: Complexity and compromises. Journal of Applied Research in Higher Education, 13(1), 272-286. https://doi.org/10.1108/JARHE-02-2020-0029

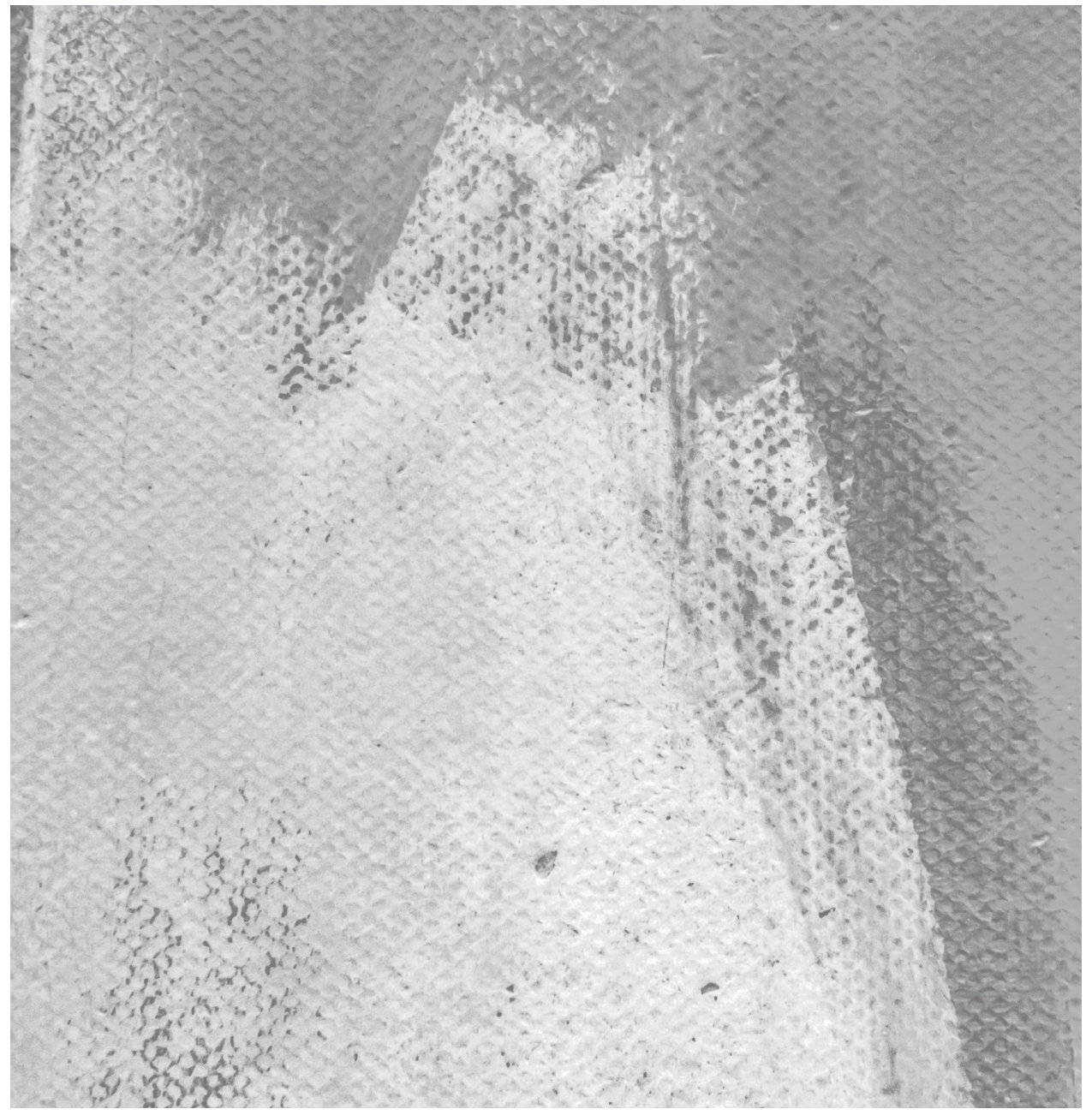

